\title{
Political opposition in patriarchal East London, 1950-1960: dilemmas of paternalism
}

\author{
D ATKINSON $^{*}$
}

\begin{abstract}
This paper describes the growing level of politicization in East London in the 1950s, and the way this affected the patriarchal normative system, which prevailed in urban administration. Patriarchalism, as a system, was susceptible of different interpretations by white municipal officials, and their response to black political opposition ranged from liberal forbearance to rigid and uncompromising intolerance. Black leaders' attitudes to the patriarchal order were similarly nuanced. The Location Native Advisory Boards vacillated between opposition to the white patriarchal order and compliance with it. Towards the late 1950 s, the political climate became ever more polarized. The paper draws on archival sources from East London to show that patriarchalism, as a moral system, was sufficiently robust to accommodate a variety of viewpoints, within the white and black communities. But as violent resistance took its toll during the 1950 s, more coercive forms of paternalism came increasingly to the fore.
\end{abstract}

Keywords: East London; Duncan Village; paternalism; patriarchalism; Native Advisory Boards; African National Congress (ANC); Verwoerdianism.

Disciplines: Political Science; Public Administration; South African History

\section{Introduction: patriarchalism in urban administration}

In every society, a normative system creates a prevailing backdrop for individual moral action. 'Ethical life' (Sittlichkeit) is an Hegelian concept referring to individuals' normative definitions of their identity, subjectivity, reciprocal rights and obligations. ${ }^{1}$ An 'ethical life' therefore consists of the inter-personal ways in which individuals recognise and constitute one another as social actors. Patriarchalism is one such system. ${ }^{2}$

The paper continues the arguments made elsewhere about the complexity of social and political dynamics in a modernising society facing rapid political change. ${ }^{3}$ It reflects on the nature of

Prof. Doreen Atkinson is attached to the Centre for Development Support, University of the Free State, PO Box 339, Bloemfontein 9300, Mobile 083 274 5461, karoo@intekom.co.za

1 D Atkinson, "Cities and Citizenship: Towards a normative analysis of the urban order in South Africa, with special reference to East London, 1950-1986.” PhD thesis, University of Natal, 1991, pp 16-17; D. Atkinson, "Patriarchalism and paternalism in South African 'native administration' in the 1950s", Historia, 54(1), 2009, pp. 262-280.

2 D VanDeVeer, Paternalistic Intervention: The moral bounds on benevolence (Princeton, Princeton University Press, 1986), p. 23.

3 D Atkinson, "Native Advisory Boards in patriarchal East London, 1950-1970”, New Contree, No. 52, 2006 ; D. Atkinson, "Complex negotiations in governance: The municipal beer hall debate in East London, 19561962", New Contree, 55, 2008, pp. 93-114'; and D. Atkinson, "Contradictions of community within local government in the 1950s, with reference to municipal beer trading”, New Contree, 57, 2009, pp.149-168. 
populist resistance to the white city fathers - a phenomenon which was by no means a simple rejection of white supremacy. Part of the focus is also on analyses of the ways in which paternalism, patriarchalism and liberalism, as three different types of 'ethical life', weaved through political life in East London in the 1950s. The article then centres on the experiences in Duncan Village, an old township which was established in the $19^{\text {th }}$ century. By the 1950 s, Duncan Village had became an overpopulated, congested and poverty-ridden slum ${ }^{4}$ - a situation which prevailed long after the creation of the modern apartheid township of Mdantsane in the 1960s.

Patriarchalism is a rational moral order, in which normative concepts (for example 'the person', or 'authority') operate within the parameters of a stable hierarchy of status and responsibility. Patriarchalism is at odds with the civil society ethos where the formal equality of persons is recognised, and social interaction is regulated by fixed and impartial rules. In modern, individualistic civil society, individuals are constituted through their mutual recognition of each other as holders of abstract, uniform, individual rights. Patriarchalism, by way of contrast, exhibits little overt regard for abstract rights. Within a system of patriarchy, the patriarch is "a more developed and more responsible moral agent" than his subordinates. The patriarch is "constituted as such by the recognition accorded him" by his charges who he regards as "persons with fewer rights but more needs than himself". ${ }^{5}$ Patriarchalism (a system of social hierarchy) is often associated with paternalistic conduct (a type of moral conduct), which can be defined as an agent doing an action with regard to another person, often against the latter's wishes, but with the express intent of promoting the interests of that person. ${ }^{6}$

Patriarchal relationships were strongly evident in the way white municipalities related to the black urban representatives who constituted the Location Native Advisory Boards. The first attempt to introduce a systematic form of black African administration was with the Natives (Urban Areas) Act of 1923. This Act empowered local authorities to set land aside for African occupations in defined "locations". In terms of this Act, 'Native Advisory Boards' were introduced in each township, to serve as a form of black representation in municipal affairs. Advisory Boards had to have a white chairperson. ${ }^{7}$ The Advisory Boards constituted an uneasy compromise between a belief in ongoing subordination, and ostensible political equality between black and white people in urban areas (albeit on a segregated basis). The Advisory Boards reflected a society in profound political and normative transition. In effect, the Advisory Boards were a double compromise: on the part of white officials, the compromise was between the more 'liberal' and the more authoritarian paternalists; on the part of the black Board members, the compromise was between conciliatory and radical black leaders. To some extent, everyone subscribed to a patriarchal order, but they defined the meaning of this very differently, and had different ideas on the future development of South African society. However, during the 1950s, the political context was undergoing profound changes. In the black community, there was a growing radicalization of opinion, with occasional outbursts of outright resistance. Black

4 E Nel, 'The spatial planning of racial residential segregation in East London', (MA Thesis, Rhodes University, 1990) p. 51.

5 W V Doniela, "Hegel and the organic state", D Muschamp (ed.), Political thinkers (London, Macmillan, 1986), p. 166.

6 D VanDeVeer, Paternalistic Intervention ..., p. 24.

$7 \quad$ R Davenport, "Historical background of the apartheid city to 1948", M. Swilling, R. Humphries \& K. Shubane, The Apartheid City in Transition (Oxford University Press), 1991, p. 7. 
mobilization and resistance increasingly met with white officials' intransigence, which undermined the vestiges of benevolent paternalism. In the white community, the National Party government was consolidating a more bureaucratic-authoritarian vision of race relations. On the eve of full-blown Verwoerdianism, the patriarchal order was coming under siege from both sides, as the East London experience so poignantly illustrates.

\section{The character of black opposition during the 1950s}

Until the 1940s, and even into the 1950s, the educated black leadership was in a contradictory position. Class distinctions in the black community were largely based on the degree of westernisation achieved by individuals, and the urge to adopt western lifestyles was strong. ${ }^{8}$ Values such as diligence, perseverance (especially in education), charity, abstemiousness, and a rejection of tribalism and ethnocentrism were cultivated by the modern black elite. Even the ANC Youth League operated almost entirely within the Christian, literate, school-going world, and its members derived self-esteem from material possessions, modern occupational skills, and western etiquette and leisure activities. Success depended on becoming 'like whites'.' Feit poignantly describes the frustrating position of the black bourgeoisie. On the one hand, they could not return to traditional society; on the other, the new technological society, which they now wished to enter and whose values they had begun to embrace, denied them a place. This 'denial of place' is an important aspect to the fundamental lack of clarity regarding the boundaries of communities in mid-century South Africa:

In his own community, [the westernised African] enjoys an exaggerated prestige because of his achievement and the resulting income he receives. But with respect to civil rights or personal liberty in the white world, he is reduced to the same level as the impoverished and illiterate African. The sense of deprivation is enhanced because the meanest White man can enjoy the rights of which the African intellectual is deprived..$^{10}$

Patriarchal city fathers felt that racial equality would threaten the basis of their moral order. Consequently, they acted in a somewhat contradictory fashion: they encouraged blacks to appreciate western values, but felt unable to include blacks in their own social circle.Despite these difficulties, the black bourgeoisie retained a strong conservative streak during the 1950s, illustrated by their strong desire to make their movements 'respectable'. "Whatever his sincerity or his capacity for leadership, [a leader] is separated from the African masses by the very achievements that give him elite status". ${ }^{11}$ This produced a reluctance to think in anti-White terms and maintained a commitment to non-violent political methods. Consequently, strong moral bonds were forged between concerned white people and the emerging black elite. The patriarchal ethos promoted these bonds, and produced a bedrock of shared normative assumptions between the two groupings.

8 E Feit, African opposition in South Africa (Stanford, Hoover Institution, 1967), p. 22.

9 GM Gerhart, Black politics in South Africa (Berkeley, University of California Press, 1978), p. 11; See also C Glaser, "Students, tsotsis and the Congress Youth League: Youth organisation on the Rand in the 1940s and 1950s" (University of the Witwatersrand History Workshop, February 1987), p. 3.

E Feit, African opposition..., pp. 27-28.

11 E Feit, African opposition..., p. 26. 
Until the 1950s, the situation offered certain important compensations for the many forms of discrimination and administrative regulations that so irked the educated black minority. Compared to the Verwoerdian excesses that would follow, the relatively benign patriarchal structures of the 1950s allowed westernised blacks (most notably, those with 'Section 10 rights' of permanent residence in the cities) some degree of liberty, dignity, protection, and social stability. This created an inherent dilemma for educated black people, as they had certain values in common with the very group that subordinated them. Generally, a subordinated group may, for a long time, vacillate between anger at the power of its superiors, and trust that its own interests will be sympathetically considered by those superiors. Shared experiences in all kinds of social institutions, such as churches and municipal government, produced amorphous feelings of affinity that obstructed the development of a militant consciousness. Blacks resented the way in which they were denied treatment in accord with certain values; they did not necessarily object to the values themselves. The Black Advisory Boards juggled the demands of township and those of white officials ${ }^{12}$, resorting to an array of moral and practical arguments. The result was a constant tactical struggle with the white city fathers, paying lip-service to white values, where necessary resorting to arguments for African traditional culture, pointing out the moral contradictions in white officials' arguments, and endlessly jockeying for influence over practical decisions such as municipal beer production. ${ }^{13}$

These dilemmas confronted the members of the Advisory Boards and the leaders of the ANC alike. The former chose to promote their values and interests through government-created institutions; the latter chose an independent and more critical forum. However, both groups were the products of patriarchalism, and hence their style of politics was often similar. In many communities, such as East London and Brakpan, black communists were responsible for a rejuvenation of Advisory Board politics during the 1940s. ${ }^{14}$ The Communist Party won all six seats of the East London Advisory Board in 1942. ${ }^{15}$ As late as 1959, the ANC's Anti-Pass Planning Council emphasised "education" of whites about the "evils of the pass laws" ${ }^{16}$ It was difficult to radically oppose an order which represented many of the western values which one admired.

In this context, local black politics in East London had a somewhat genteel character. For example, a mass demonstration was held in April 1951. Township residents protested against an increase in rentals. The demonstration was approved by the Police and the City Council, and was held in the city centre. Four thousand protestors marched in orderly procession, and sang Nkosi Sikeleli Afrika outside the City Hall. Youth League marshals "walked on either side of the column, preventing it from straggling, bunching or spreading", and motorists courteously gave way. The Mayor met a delegation of the protesters - but their demands were turned down. ${ }^{17}$ At

12 D Atkinson, "Native Advisory Boards in patriarchal East London, 1950-1970”, New Contree, No. $52,2006$.

13 D. Atkinson, "Complex negotiations in local governance"; and D. Atkinson, "Contradictions of community within local government .."

14 T Lodge, "Political mobilisation during the 1950s: An East London case study", S Marks \& S Trapido, The politics of race, class and nationalism in twentieth century South Africa (London, Longman, 1987), p. 321.

15 D Everatt, “The origins of multiracialism”, (African Studies Institute Seminar, University of the Witwatersrand, 1990), p.3.

T Lodge, “Political mobilization...”, S Marks \& S Trapido, The politics of race..., p. 317. 
the annual meetings of the Institute of Administrators of Non-European Affairs (IANA), a variety of strands of highly ambiguous segregationist and paternalist arguments were repeatedly invoked to make sense of increasingly complex black urban areas. ${ }^{18}$ Government's appropriate response to black protests was often discussed. Many municipal officials felt that such orderly protests should be allowed. Mr. Bourquin of Durban, for example, expressed his reservations about the prohibition of meetings:

\section{It is far safer to allow people to express themselves and 'to blow off steam' than to muzzle them and to drive them underground. Unless there is actual incitement to break the law or to create violence and disorder, and there are laws in existence to deal with such a situation, people must be permitted to assemble and to express their views, even if such views are of a critical or even challenging nature. ${ }^{19}$}

Mr. Bourquin's attitude was that of an intuitive compromise between patriarchalism and liberal rights. He felt that blacks' political meetings were relatively harmless ("blowing off steam"), and possibly reflected the normal frustrations experienced by children under the yoke of their parents' authority. Yet he concluded his address to IANA by quoting Voltaire: "I may violently disagree with what you say, but I shall defend to my last breath your right to say it". His patriarchalism and his liberalism were tempered by a healthy awareness that patriarchs are not always right, and that they can, intentionally or unintentionally, abuse their powers. It was therefore in everybody's interests that their wards had the right to express their frustrations or grievances. This, of course, did not imply that the city fathers should satisfy all of their demands; it simply affirmed their right to express their wishes. In contrast, Mr Roux of Klerksdorp advocated taking a tough line on political 'agitation':

These days, there are many irresponsible Bantu who ... whip up local residents and preach untruths to them. They usually exploit the opportunity to prepare residents for the agents which organize strikes, demonstrations, etc., behind the scene. ${ }^{20}$

The issue was never satisfactory resolved at IANA, and each locality was left to figure out an appropriate response to black mobilization.

\section{Radical resistance in East London, 1952}

Simultaneously, however, government policy forced the black elite to remain in the black urban ghettoes. There was a considerable area of shared experience between middle-class political notables and their proletarian neighbours. Notwithstanding the growing class polarisation in the townships, the black elite still felt responsible for improving the lot of their community as a whole. This produced a rather tentative kind of radicalism:

The African bourgeois is by force of circumstances rather than through personal choice a radical. His entry into the political arena is perhaps less due to his own wish to participate in radical politics than to the feeling that, being forced to the same level as the masses by

D Atkinson, "Patriarchalism and paternalism ...”, pp. 262-280,

19 Institute of Administrators of Non-European Affairs (IANA) (Annual Conference Proceedings, Bloemfontein, 1956), p. 46. 
external constraints, he must break the system in order to establish his supremacy over them. ${ }^{21}$

Because the black educated elite was forced to live cheek by jowl with the black underclass, it inevitably felt that it had an especial competence in defining the real interests of that underclass. Yet the curious mixture of strict supervision and benign tolerance which characterised patriarchalism was difficult to challenge. The black elite had to contend with white officials, who, in the spirit of a benevolent paternalism, also claimed the right, and competence, to define the real interests of black residents. The upshot was a low-key tug-of-war, in which moral argumentation, political pressure, and threats of coercion or resistance, were employed to determine the definition of blacks' 'real interests'. This happened on an ad hoc, particularistic, case by case basis. The result was often frustrating, but seldom sufficiently threatening to challenge the fundamentals of patriarchal paternalism. There was always the chance to live to fight another day. The strange combination of tolerance, benevolence and coercion which constituted the delicate fabric of patriarchalism came to be truly appreciated only with the onset of the Verwoerdians' moral extremism and totalitarianism. Increasingly, the Afrikaner Nationalists:

... disturbed the perfect tranquility of the African middle class, mingled them with the commonality; the old guard [the black elite], the masters of consultations and concessions and compromises, found themselves without a protector, commingled with the common dust; then out of expedience, rather than loyalty, they looked for recognition in that instrument of rebellion, the African National Congress. ${ }^{22}$

It was only during the 1950s that the ANC Youth League (ANCYL) persuaded the organisation that the time for confrontation through passive resistance had arrived. The new militancy was a reaction to increasingly strident National Party policies, which caused a variety of non-white groups, as well as the South African Communist Party, to resort to violent protests and ruthless repression, between 1949 and 1952. Elsewhere in the country, mass protests reached a peak in April 1952. The Defiance Campaign was planned to coincide with the tercentenary of Jan van Riebeeck's arrival at the Cape. Civil protesters in many cities, including East London, entered black locations without permits, broke curfew laws, and defied "Europeans only" notices in public places, thus inviting arrest. ${ }^{23}$

In the light of this heightened political temperature, black political opinion in East London also underwent a sea-change. The ANC was split between a conservative, older, cautious wing ('Congress A'), and the ANCYL, which formed a branch in East London in 1949. The latter was led by three young men, CJ Fazzie, AS Gwentshe and J Lengisi. This group was more militant than its elders, and emphasised the values of racial dichotomy, cultural self-sufficiency and a heroic past. The Youth League frequently opposed participation in Advisory Board politics, to the annoyance of Congress A. ${ }^{24}$ This phase of militancy in East London was very intense, but did not last long. During the nation-wide Defiance Campaign of 1952, the militant youth in East London also planned protests against government legislation. The ANC's argument that black

21 E Feit, African opposition..., p. 29.

22 B Modisane, Blame Me on History (London, Thames \& Hudson,1963), p. 46 quoted in E Feit, African opposition..., p. 29.

23 TRH Davenport, South Africa: A Modern History, (London, 1991), p. 335.

24 T Lodge, "Political mobilization...", S Marks \& S Trapido, The politics of race..., p. 322. 
people were entitled to rights in the land of their birth found enthusiastic support amongst the residents. Under the leadership of the ANC, black residents challenged the laws which imposed the curfew, service contracts, and permits to seek work. Hundreds of volunteers entered the streets at night, without night passes or service contracts. All were arrested. By the end of the campaign, about 1500 persons had been convicted..$^{25}$

As the year drew on, the black residents of Duncan village became increasingly militant. Disaffected youths, imbued with a pride derived from Africanism, yearned for action. ${ }^{26}$ In November 1952, the government decided to prohibit all public meetings of black residents, in terms of the Riotous Assemblies Act, No. 22 of 1930. In spite of the ban on public meetings, a crowd gathered at the Bantu Square on the afternoon of 9 November 1952, ostensibly to hold a religious service. A detachment of armed police dispersed the crowd by force, and several demonstrators were killed and wounded. The police had just withdrawn to the police station, when news reached them of the murder of a Dominican medical nun, and an insurance salesman. The crowd had reached a pitch of frenzy. The badly mutilated body of Dr. Elsie Quinlan had been partly cannibalised with a view to ingesting the victim's magical powers as a doctor. The crowd subsequently vented its pent-up rage by burning the Roman Catholic mission building, the teacher-training school, and the commonage ranger's house. Thousands of residents fled the township and sought refuge in rural homesteads.

The Defiance Campaign had been overtaken by unforeseen social realities. The riot had been touched off in the shack area. While the more respectable residents of the municipal housing area stayed behind closed doors, the tsotsi youths went on the rampage. DH Reader explains the social dysfunction that gave rise to the tsotsi phenomenon:

Offspring of temporary and shiftless liaisons, involuntary by-products of one of the few leisure-time activities available to the shack-dweller, they had come into the world unwelcomed and unloved, an additional burden on already overtaxed resources, born into disease, squalor and inadequate homes. Often, by a hideous process of natural selection, these gangs were the more alert, the more crafty, the more vicious of an unorientated and dispossessed class... Generations of regimentation and neglect had produced from the slums the fury which erupted through their offspring. The tsotsis, unlike the majority of adults present at the time, were able to strike in an ecstasy of abandon, with no property, no future, no employment, nothing to lose save their seemingly worthless lives. ${ }^{27}$

The Defiance Campaign in East London was quickly brought to a halt. The older and more respectable residents were appalled at the excesses of the younger element, especially at the gruesome murder of an innocent woman many of them had known and respected. The ANC lost several key leaders through imprisonment or banishment. ${ }^{28}$ Lengisi, Fazzie and Gwentshe were arrested and tried for incitement. Lengisi and Gwentshe were banished from the Eastern

25 See DH Reader, The black man's portion (Cape Town, Oxford University Press, 1961) for a graphic account of the 1952 disturbances.

26 A Mager \& G Minkley, "Reaping the whirlwind: the East London riots of 1952", P. Bonner, P. Delius and D. Posel (eds), Apartheid's Genesis: 1935-1962 (Johannesburg: Ravan, 1993), 229-251.

27 DH Reader, The black man's portion, p. 28.

28 East London Municipal Archives, manager's report to Native Affairs Committee (NAC), 12 February 1954, referring to the sentences on Mr. Gwentshe and Mr. Lengisi passed on 26 March 1953. 
Cape and removed to a remote village in the Transvaal. In East London, the events of 1952 were a political disaster for the ANC, as many of its followers were alienated by the violence. According to Lodge, the residents of Duncan Village immediately associated the riot with the ANC, and were no longer willing to identify themselves publicly with it. The Defiance Campaign of 1952 therefore marked both the zenith and the nadir of the Youth League in East London. For some years after the riot of 1952, there ensued a political vacuum in Duncan Village. ${ }^{29}$ In this situation, the Advisory Board regained some significance. Various factors led to an increased acceptance of the Boards in township life. In the face of fear of the police, many blacks were not prepared to resort to more radical forms of political action. ${ }^{30}$ Furthermore, for many politicised people, 'non-violence' was a matter of principle as much as tactics, and educated blacks were still deeply influenced by liberal values. ${ }^{31}$ But political life was never the same again. The old liberal demands took on a more collectivist colour with the Freedom Charter of 1955. The claim by ANC leaders to comprehend the 'true interests' of black people became ever more compelling.

\section{The growing assertiveness of the Location Advisory Boards}

In 1955 in East London, the ANC once again contested the Advisory Board elections. ${ }^{32}$ Politicised Advisory Board members saw themselves as a beleaguered group, under increasing pressure from the central government to refrain from holding critical political views. The ANC members of the Board soon became disillusioned with the sluggish implementation of township improvements. This disenchantment gradually developed into strident criticism of administrative policies. The role of the Advisory Board was strengthened by the distinctly localistic colour of black populism during the 1950s. During this period, the ANC's role as a community organisation responding to local sources of discontent was of greater significance to the people than its national programme of action. The energies of both local and national ANC politicians were often expended on trying to bring localized, 'subsistence orientated' popular movements within the ANC's sphere of influence. ${ }^{33}$ The ANC was organisationally unable to exert much control over its branches, with the result that local issues tended to preponderate in the branches' deliberations. ${ }^{34}$ This had two important consequences. On the one hand, the emphasis on local grievances and goals suited the political style of the Advisory Boards, and strengthened their links with the ANC; on the other hand, however, this very localism had the unintended consequence of sustaining the patriarchal ethos in the cities, as local black leaders' energies were taken up in piecemeal tussles with white municipal officials.

The Native Advisory Boards did more than merely convey township residents' desires and grievances to the Council. They had a nascent political consciousness of their own. The Duncan Village Advisory Board also participated in the Location Advisory Boards' Congress, which

29 T Lodge, "Political mobilization...", S Marks \& S Trapido, The politics of race..., p. 324.

$30 \quad$ E Feit, African opposition..., p. 89.

31 T Lodge, “Political mobilization...”, S Marks \& S Trapido, The politics of race..., p. 317.

32 East London Municipal Archives, manager's report to NAC, January 1957.

33 T Lodge, "Political mobilization...”, S Marks \& S Trapido, The politics of race..., p. 314.

34 E Feit, African opposition, p. 68. 
brought together Advisory Boards throughout the country. This Congress concerned itself with urban blacks' practical grievances. ${ }^{35}$ The East London Advisory Board was well represented amongst the Congress leadership. ${ }^{36}$ The Advisory Boards' Congress issued political statements and also criticised national policy. For example, it urged the Government to repeal the Bantu Education Act. ${ }^{37}$ The Advisory Boards' venture into national political questions, as opposed to matters pertaining only to their urban localities, caused real alarm amongst white officials. On this score, municipal and Departmental officials were in agreement: the Boards were overstepping the mark. At stake was the unresolved definition of blacks' 'interests'. For the Advisory Boards, national issues affected the interests of their constituents, and hence ought to be discussed. Significantly, this position found some support amongst those white officials who subscribed to a more liberal type of paternalism. Even during the radical protests in Duncan Village township in 1952, some white United Party Councillors still explicitly defended the residents' right to protest. ${ }^{38}$ They wanted to meet with "responsible native elements", including the ANC, on condition that "the Natives in their turn would give assurance that they would bring the situation back to normal". These Councillors clearly believed that some credence had to be given to black leadership, and that whites' interpretations of black residents' problems were deficient. Once again, it was a liberal form of paternalism that was being enunciated. In the words of Mr. Ford, the Superintendent of Duncan Village:

I wish to differ from the contentions of my predecessors. Although the context of many of the discussions may be negative, it must be borne in mind that the Advisory Board is the only Government recognised mouthpiece the native has, and with a little guidance and assistance, may be moulded into a useful body insofar as Urban Native Administration is concerned ... I am sure that at Congresses and the like, good, constructive criticisms will be advanced and better understanding between black and white will exist. ${ }^{39}$

Mr. Ford's statement aptly identified a major source of the problem, viz. the lack of clarity regarding the appropriate mouthpiece for blacks' opinions. The steady growth of the African National Congress (ANC) pushed this question to the fore. However, many white officials, and more especially those with Verwoerdian inclinations, believed that white authorities were the appropriate agencies to determine what measures were in the interests of black people at national level. They believed that Advisory Boards were only competent to pronounce on blacks' local interests. East London's Township Manager, who also attended the 1954 Advisory Board Congress meeting, criticised the performance of his Advisory Board in this regard. His view was crucially based on the distinction between national ('political') issues and local ('welfare') matters:

The Secretary for Native Affairs addressed the Congress and ... outlined the policy which it
is intended should lead to self-help, self-government, improved living conditions and

35 P Rich, “Managing black leadership...", P Bonner et.al., (eds.), Holding their Ground, pp. 182 and 186.

36 For a fuller account of Native Advisory Boards in East London see D Atkinson, "Native Advisory Boards in patriarchal East London, 1950-1970", New Contree, 52, 2006, pp. 49-63.

37 East London Municipal Archives, report by Superintendent of Locations to NAC, 14 January 1954.

38 East London Municipal Archives, report by Superintendent of Locations to NAC, 11 November 1952.

39 East London Municipal Archives, report by Superintendent of Locations to NAC, 16 March 1956.

TD, 6(1), July 2010, pp. 175-190. 
employment, etc. He invited questions and suggestions from Congress. He received [nothing but] political criticism. ${ }^{40}$

The Township Manager continued that he believed that the Advisory Boards' Congress was irresponsible and prejudiced:

I cannot describe the Congress proceedings better than by saying that they were absolutely negative. There was no constructive criticism or suggestions. Everything explained was turned down.

The hostility of the national Department of Native Affairs (DNA) to these events was even more pronounced. The Minister, Dr. H.F. Verwoerd, was unsympathetic and uncompromising. His view was based on the same distinction between local/practical matters, and national/political matters. He claimed that the former represented the real interests of black people, while the latter was no more than a distraction from the Boards' proper role. In a letter to the Advisory Board Congress, the Departmental Secretary stated that

the function of the Congress is to deal with matters of urban Native Administration and ... discussions of national policy do not fall within its scope of activities. ${ }^{41}$

The DNA also announced that, in future, municipalities would not be allowed to finance their Advisory Board members' travel costs to the Congress venues. ${ }^{42}$

East London's Town Clerk felt that the Department's attitude was fully justified, "and it has now become abundantly clear that the Department's efforts to steer the Congress back to a course which would redound to the benefit of the local interests of the Natives concerned, have failed." ${ }^{43}$ However, the Advisory Board subscribed to a different conception of 'interests'. It therefore refused to give up its right to discuss national issues. The Congress leadership wrote to all local authorities ${ }^{44}$, defending the view that Advisory Boards were competent to judge the true interests of their constituents. They based their argument on the Native (Urban Areas) Act of 1945, which required the Boards to "report upon any matter specially affecting the interests of Natives in the urban area, or upon which the Board may consider it useful or desirable to report”. In terms of this provision, Congress considered certain legislation, such as the Bantu Education Act, to qualify as affecting their constituents' interests. The Congress also felt that the resolutions taken on the issues of passes for women, revision of rentals, and housing, fell within its legitimate purview.

The uneasy status quo in township political dynamics was not overly comprehensible to white officials and councillors in South African towns. It was one thing to be confronted with requests for township improvements; it was quite another to deal with the demand for the right to have a

40 East London Municipal Archives, report by Superintendent of Locations to NAC, 22 January 1953.

41 East London Municipal Archives, letter from Secretary of DNA to Advisory Board Congress, forwarded to Town Clerk by DNA on 19 December 1955.

42 East London Municipal Archives, Town Clerk's report to NAC, 4 October 1956, quoting DNA circular dated 6 September 1956.

43 East London Municipal Archives, Town Clerk’s report to NAC, 4 October 1956. Emphasis added.

44 East London Municipal Archives, undated letter to local authorities, recorded in Town Clerk's report to NAC, 4 July 1957. 
say in the broader issues affecting black residents. Local white officials had very little insight into the complex political strands in the black community, and in particular, the ways in which local problems were influenced by national policies. Furthermore, an unarticulated question of objective versus subjective interests was absolutely fundamental. The problem of distinguishing between the 'real'(objective) interests of urban residents and their expressed (subjective) wishes, bedevilled every aspect of the officials' handling of the political undercurrents. On top of this lack of comprehension, the policies of the central government became ever more strident and uncompromising, thereby propelling officialdom in the direction of ever more coercive forms of paternalism. One factor in accounting for the restiveness of the Advisory Boards was the perceived presence of 'agitators'. This perception was repeatedly discussed at Institute of Administrators of Non-European Affairs (IANA) conferences, without achieving much clarity on the matter. The question of political grievances was another matter which received attention. While the white city fathers could admit that the underclass had vague rights to decent treatment (generally at the discretion of the white officials), the question of political rights (such as rights of expression, assembly, and franchise) seemed to threaten the existing ethical order. As whites perceived it, patriarchalism had hitherto been the most benign and viable kind of relationship - infinitely preferable to slavery, subjugation or overt hostility. The political currents in the locations led to a crucial question. In terms of the analogy of the family, should political 'adolescents' have political rights? Could their judgment be trusted, or did their elders ultimately have better insight into what was good for them?

The differentiation of subjective and objective interests is a tricky undertaking at the best of times. Many doctrines, including fascism, socialism, communism and paternalism, have claimed that people have 'real interests' of which they may be unaware. This has, on many occasions, led to the suppression of people's 'mere wants' in favour of their putative 'real interests'. (It is only liberalism that has stood strongly for the political recognition of subjectively defined interests, i.e. wishes). It is not surprising, therefore, that white officials, when confronted with political opposition, and faced with the problem of creating and defining the urban community, should have been tempted to take political short-cuts, and define for themselves what the 'real interests' of the black residents were. From within the patriarchal order, it was very difficult for white officials to conceive of blacks as being the bearers of rights equal to those of whites. The notion of individual political rights is a sophisticated formulation, based on a highly developed notion of individualism. The moulding of modern subjectivity is the sine qua non of individualistic democratic rights. Also presupposed is a very durable and solidly woven social fabric, based on Foucauldian 'disciplinary' social institutions (schools, armies, factories, hospitals). These recast the pre-modern person as an orderly, predictable, self-restrained individual. Modernity also implies a certain minimum of social coherence, and shared definitions about the limits and organisation of the community. In Europe, the development of rights and democracy was accompanied by the development of deeply entrenched "social discipline".

In South Africa during the 1950s, the quest for individual rights by the black disenfranchised was a normal part of the process of growing individuation produced by a modernising society. However, the social context was ambiguous and unresolved. Black political grievances were expressed within a turbulent and unstable urbanising society, with major demographic shifts, and an unresolved definition of the urban community. The exercise of authority, and voting patterns, in the townships certainly did not exhibit much in the way of individualism or modernity. Whatever control was exerted in these squalid areas was done through a combination of benign paternalism and crude, violent (often relatively ineffective) bureaucratic repression. Municipal officials countrywide were alarmed at the growing social distress, crime, violence, and decline in moral standards which characterised the urban locations. The assertion of individual political 
rights would, so it was believed, strike at the heart of both patriarchalism and coercion, without the bedrock of social discipline to prevent the entire society from flying apart. The officials' forebodings of chaos and instability translated into a feeling that political rights for the masses of blacks were simply inappropriate.

Given the violent events of the 1952 Defiance Campaign, these fears were not entirely without foundation. Furthermore, Tom Lodge's study of East London describes radical black politics in East London as "socially inchoate" during the 1950s, due to the recent rural origins of many of the residents and the impoverished living conditions in the township. Rurally derived culture remained influential, and adherents of 'Red' (traditional) ideology roughly matched the so-called 'School' converts to Christianity. ${ }^{45}$ The memory of the fateful events of 1952 lingered on in the consciousness of the East London city fathers. Fifteen months later, the Duncan Village Township Manager presented his Council with apparent evidence of ANC attempts at subversion. A chain letter had been found, which advocated violent revolution. The letter contained the following text:
The black man is being prosecuted, jailed, fined, assaulted, murdered and denied education. God will help us if we try to help ourselves... Every non-european must burn the white man's property. You are ordered to set a light to the veld and also Post Offices and Dutch Churches in town. Use paraffin and dry wood... Travel in motor cars to distant towns to burn European schools... When travelling pull down telephone lines and road signs. Burn farmers tractors, cars, barns, veld, haystacks and stores, especially Nat. Afrikaners enemies [sic]. Post this to all friends black and white, or be cursed, unlucky and damned to hell for ever and ever-Amen. ${ }^{46}$

In the light of the officials' impressionistic understanding of black politics, it is little wonder that black demands for individual political rights caused such unease on the part of white local officials and City Councillors in South African towns. It was one thing to respect the judgment of acknowledged black leaders; it was quite another to visualise shiftless tsotsi's having equal political rights. Officials' sense of social fragility was severe enough already. They had neither the habits of mind, nor the social institutions, to understand or accommodate the emerging style of black politics. But the officials' commonly held anxieties did not translate into consensus on how to deal with the problem of black political opposition. What was to be done about the grievances of people most of whom were entering the cities for the first time, and who shared few of the cultural traits of the white sectors of the cities? Should blacks be forcefully kept within their subordinate role, or were they entitled to have an opinion of their own? Did they have rights or not? Did their expression of their wishes reflect their own 'real interests'? Did the socalled 'agitators' propagate false conceptions of blacks' needs, or should their claims be taken seriously?

\section{Towards coercive paternalism}

It can be generalised that, the stronger officials' belief in the need for an initiating, pioneering approach to 'native development', the more they adopted a messianic role, and the more coercive their paternalism became. Paternalism may be represented as lying on a continuum. At one extreme were officials satisfied to allow urban blacks to 'progress' pragmatically with a loose 
and liberal combination of rights and controls. At the other extreme were more Nationalistorientated officials who felt a need to reconstruct black urban community life on a traditional ethnic basis. The former often took blacks' articulated wishes into consideration; the latter tended to emphasise attributed ('ethnic') needs and interests. Another dynamic was also taking place, in a minor key. The more the local officials attempted to block local blacks' political aspirations, the more those officials had to rely on the material resources and the moral rationales offered by the central government. In effect, such municipal officials abdicated their local authorities' inherited right to deal with local conflict in a manner they thought fit. They were steadily becoming locked into a dependency relationship with the Department and other coercive central government agencies. This relationship can be characterised as a displaced patriarchalism: local officials looked to central government officials for paternalistic guidance.

Ultimately it was coercive patriarchalism that prevailed over the proto-liberal discourse of officials like Mr. Bourquin. These ambiguities in applying paternalism opened the way for the totalitarian intervention of the Verwoerdians, with their clear vision of the kind of citizenship for which blacks should be prepared. For Dr. W. M. Eiselen, Secretary of the Department of Native Affairs, the goal of ethnically-defined polities was such an intrinsically reasonable one, that the government was justified in employing strict measures to bring it about:

Can the Department of Native Affairs be accused of being frivolous and of drafting its laws in so unreasonable a manner that a well intentioned Native finds it difficult or unduly irksome to comply? I have no hesitation in denying this most emphatically ... There are Natives who consider that they have risen above and no longer belong to their community and therefore desire to be exempted... Socially such relaxation would have the detrimental effect ... [of] encouraging such persons to turn their back on their own society. ${ }^{47}$

Dr. Eiselen's views would prove highly persuasive, because he articulated an anxiety shared by local officials, viz. the sense of impending chaos:

We are dealing with a mixed Bantu population ... which lives cheek by jowl with the European community and is during the working day subject to all sorts of influences, completely divorced from Bantu custom and Bantu interests ... The urban Bantu population is exposed to the deliberate, near subversive propaganda of a number of selfseeking agencies .... ${ }^{48}$

The agitators threatened the entire legal system, Dr. Eiselen continued:

The Natives' laws are discriminatory, the Native is told; they are unjust, outrageous, vicious and so forth. Why then should he obey them? And if he is morally justified in evading or breaking some particular law, why not another, why not any law? ... What is remarkable is that the vast majority still remain law-abiding .... 
Faced with the spectre of total lawlessness amongst black urban residents, the Verwoerdian officials felt their task to be an extremely urgent and important one. Traditional communities had to be resuscitated precisely to retain and recreate a respect for the law. It was the only way to preserve any form of social organisation whatever, and almost any means could be employed to reach this goal. Whereas Mr. Bourquin's solution had entailed the recognition of rights, wishes and subjective interests, the Verwoerdian approach was based on the notion of 'real interests', based on traditional community identities. For the Verwoerdians, the notion of rights for blacks became superfluous; indeed it was an obstacle to recognizing their true interests. The Verwoerdians' remarkable sense of conviction seduced many local officials. In the words of Councillor Tredoux of Boksburg, "We must be steadfast, we must choose a direction and that direction is now being indicated to us, not by ourselves, but by the authorities, and we should follow it". ${ }^{49}$ The next section examines the way in which East London officials also began to resort to coercive methods in dealing with black opposition.

\section{East London's response to political opposition during the 1950s}

Patriarchalism did not hold out clear guidance on how to deal with political opposition. In East London, officials and Councillors held different opinions on the matter. A key question was the relationship between the ANC and the Advisory Board. Should a cordial working relationship between the two organisations be maintained, or not? The township officials, and most notably the Township Manager, directed their efforts at trying to drive a wedge between the ANC and the Advisory Board. The general political atmosphere no doubt shaped their perspective. Security issues were prominent in the central government's priorities during the 1950s, and the Suppression of Communism Act was passed in 1950. In 1953, the government introduced the Public Safety Act, enabling it to declare a state of emergency in the country; the Criminal Law Amendment Act of 1953 increased the maximum penalties for persons convicted of offences committed by way of protest against any law. ${ }^{50}$ The Township Manager, Mr. Venter, accused the ANC leaders, Mr. Lengisi and Mr. Gwentshe, of intimidating the black populace. He claimed that headmen were being attacked, municipal employees intimidated, and public meetings of the Advisory Boards obstructed by the ANC Youth League. On one occasion, the Manager reported that, on an inspection tour of the location, he and the Mayor "were lucky to come out alive." 51

There were two courses of action open to the Council, and Mr. Venter firmly pursued both. First, he felt that it had become necessary to refuse the ANC the use of the municipal hall in the location. "When they use it, it is picketed and collections made for the adverse activities of the movements." The Township Manager believed that the 'responsible' black residents did not approve of the activities of the ANC. "The position is so bad that residents at the risk of being arrested will leave their homes in the vicinity of the [Peacock] Hall if there is a meeting of the ANC." ${ }^{2}$ The Council accordingly informed the ANC that it was not allowed to use the Peacock

IANA (Annual Conference Proceedings, Bloemfontein,1957), p. 83.

M Horrell, Action, reaction and counteraction (Johannesburg, SAIRR, 1963), p. 12.

East London Municipal Archives, Township Manager's report to the Public Health and Non-European Affairs Committee, 12 February 1954. 
Hall for any purpose whatsoever. ${ }^{53}$ However, the local ANC committee still managed to find ways to continue with its activities, and an irate Township Manager reported in August that the National War Memorial Health Foundation's Community Hall had been used for an ANC meeting. ${ }^{54}$ The other course of action open to Mr. Venter was the deportation of leaders. Regulations regarding deportations were steadily becoming more severe. In September 1956, the Secretary of Native Affairs notified local authorities that, in terms of the Natives (Urban Areas) Amendment Act of 1956, municipalities could deal more effectively with any persons deemed "detrimental to the maintenance of peace and order". Any 'agitators', including those with Section 10 rights, could be ordered to leave the urban area. Departmental approval for such action was no longer necessary. ${ }^{55}$ The Department advised local authorities that the rationale behind deportations was that "the Native concerned should be given every possible opportunity to mend his ways". ${ }^{56}$ It remained the task of the City Councils to determine whether an offender had indeed 'mended his ways'.

In April 1954, the Township Manager suggested that the Department of Native Affairs be asked to remove the ANC leaders, Mr. Lengisi and Mr. Gwentshe, from the location. The City Council approved this suggestion. ${ }^{57}$ The Township Manager was sceptical about the likelihood of Lengisi and Gwentshe ever changing their spots. In 1956, the Native Commissioner informed the Town Clerk that Mr. Gwentshe had "acknowledged the error of his former ways and that he is prepared to co-operate with the authorities in future." 58 The Manager remained unconvinced. He maintained that Gwentshe had been in correspondence with the local ANC, and that he had been elected president in absentia. The Manager's response was indicative of the persuasiveness of coercive paternalism, especially when it is based on a familiarity born of firsthand local contact:

The return of Gwentshe to East London... leaves nothing to imagination. We in East
London have known Gwentshe somewhat longer than the Department of Native Affairs
and it will take something more than just a mere acknowledgement from Gwentshe to
convince this office that he has seen the error of his ways. In fact, he has 'seen the error of his
ways' on many an occasion before today and whilst there is comparative calm in the
location it is felt that Gwentshe's return should be very strongly opposed.

A similar correspondence took place about the future of Joel Lengisi. In 1958, Lengisi appealed to the Secretary of Native Affairs for permission to return to East London. The pathos of his request was unmistakable:

East London Municipal Archives, minutes of NAC meeting, 21 May 1954.

East London Municipal Archives, Township Manager's report to Town Clerk, 5 August 1954.

55 East London Municipal Archives, Department of Native Affairs (DNA) circular to local authorities, 15 September 1956.

56 RE Pretorius, "Banishment: Germiston's answer to opposition in Natalspruit Location, 1955-1957" (University of the Witwatersrand History Workshop, 1987), p. 3.

East London Municipal Archives, Township Manager's report to NAC, 27 April 1954.

58 East London Municipal Archives, letter from Native Commissioner to Town Clerk, 28 September 1956, quoted in Town Clerk's report to NAC, 6 November 1956. 
Sir, you will recall that since I was banished from East London in July 1954 I have never earned a living ... I have suffered irreparable and untold harm ... During Sir, my period of banishment, I was very loyal to the authorities and I promise to do so even in future. Sir, I wish to inform you that my belongings and financial matters have been ruined in East London, and I earnestly appeal to you, Sir, to allow me to join my former employment. I am fully prepared, Sir, to abide by any undertaking ... . ${ }^{60}$

Once again, the Manager remained unmoved. He claimed that Lengisi was still in contact with the ANC. The Township Manager was supported by the Native Commissioner, Mr. Pike: "Personally, I am opposed to Lengisi returning to East London as his mere presence here will strengthen the African National Congress." ${ }_{11}$ It must be appreciated that the officials' attitude towards political opposition was not solely shaped by the ANC but was influenced by many other day-to-day events and relationships in the townships. The leadership of the Industrial and Commercial Workers' Union (ICU) in East London had, for instance, a close patriarchal relationship with the officials. As the Secretary of the ICU wrote to the Township Manager:

The late Mr. Clements Kadalie taught the members to fight for the rights of the members but at all times to respect and obey the laws of the country and the Government in power. We do not wish to go off from this clear path... You are the local father of peace. We, as law-abiding citizens under you are, we think, entitled to your protection.... ${ }^{62}$

Given the subservient, respectful tone of this letter, how could the ANC's assertiveness have appeared to be anything other than subversive and unreasonable to officialdom?

\section{Conclusion}

The patriarchal normative system might have lasted indefinitely, had it not been for the pressures of modernisation building up in the urban townships and the resulting wave of violent opposition to the white government. The black bourgeois elite subscribed to a notion of equal political rights, which encouraged them to become politically articulate. This threw the patriarchal system into disarray, for many of the city fathers were unable to cope with this development. A latent defect in patriarchalism, viz. the confusion between needs and wishes, became an overt and chronic moral problem. Some officials tried to deal with this state of affairs via recourse to liberal or 'permissive' forms of paternalism, whereas others increasingly preferred to resort to coercion. The East London Locations Advisory Board became radicalized, and developed its own reference group at national level. The patriarchal normative ideal became ever more tenuous and contested, and prepared the ground for the full onslaught of Verwoerdian controls.

60 East London Municipal Archives, letter from J Lengisi to Secretary of DNA, 4 December 1957, quoted in Township Manager's report to NAC, April 1958.

61 East London Municipal Archives, letter to Town Clerk, 7 March 1958, quoted in Township Manager's report to NAC, April 1958.

62 East London Municipal Archives, letter to Superintendent, 1 May 1957, quoted in Township Manager's report to NAC, March 1958. 